\title{
A prospective comparison of local and spinal anesthesia for inguinal hernia repair
}

F. Ayca Gultekin • Osman Kurukahvecioglu • Ahmet Karamercan • Bahadır Ege • Emin Ersoy • Ertan Tatlicioglu

Published online: 6 March 2007

(C) Springer-Verlag 2007

\section{Erratum to: Hernia}

\section{DOI 10.1007/s10029-006-0166-3}

Due to an unfortunate mistake the name of $\mathrm{Dr}$ Kurukahvecioglu was misspelled. Please find the correctly spelled name in the author line and the footnote.

The online version of the original article can be found at http://dx.doi.org/10.1007/s10029-006-0166-3.

F. A. Gultekin · O. Kurukahvecioglu · A. Karamercan ·

B. Ege $\cdot$ E. Ersoy $\cdot$ E. Tatlicioglu

Department of Surgery,

Gazi University Faculty of Medicine, Ankara, Turkey

O. Kurukahvecioglu $(\bowtie)$

Genel Cerrahi Anabilim Dalı,

Gazi Üniversitesi Tıp Fakültesi,

Beşevler, Ankara, Turkey

e-mail: okurukahveci@yahoo.com 